\title{
Tuulia Toivanen
}

\section{"Ennen muuta kääntäjän pitää rakastaa äidinkieltään" Haastattelussa kääntäjä Oili Suominen}

\author{
Grass, Lenz, Wolf, Schlink, Sebald... Kun suomalainen \\ lukija poimii käsiinsä käännettyä saksalaista \\ kirjallisuutta, hän löytää ensilehdeltä toistuvasti saman \\ tiedon: suomentanut Oili Suominen.
}

Oili Suomisella on nyt takanaan huimat 40 vuotta kääntäjän taivalta. Suomentajan uraa hän mietti ensi kerran jo nuorena opiskelijana:

- Ajatus ryhtyä kirjallisuuden kääntäjäksi, sen tiedän aivan tarkalleen, Suominen hymyilee. - Olin Lyypekissä lukion ensimmäisen luokan jälkeen stipendiaattikurssilla, ja me osallistuimme siellä äidinkielen eli saksan opetukseen. Keskusteltiin Wolfgang Borchertin novellista "Nachts schlafen die Ratten doch". Silloin minä ajattelin, että tämä pitäisi kääntää suomeksi.

Borchertin novelli oli tuolloin jo ehditty kääntää, mutta ajatus jäi Suomisessa itämään. Ensimmäiseksi käännöstyökseen hän muistaa Günter Eichin kuunnelman "Sabeth, lintuvieras" (1965):

- Väinö Kirstinä oli silloin Yleisradiossa dramaturgina. Hän neuvoi jossakin haastattelussa kirjailijoita, ettei kannata kirjoittaa pöytälaatikkoon, vaan antaa tekstit luettaviksi. Sovelsin Kirstinän ohjetta myös suomentajiin ja tarjosin käännöstäni Eichin kuunnelmasta, Suominen kertoo. - Sain vastauksen, joka oli osoitettu "arvoisalle suomentajalle".

Sen jälkeen käännöstöitä on riittänyt. Alun perin arkkitehdin uraa suunnitelleen Suomisen tie vei Porin tyttölyseosta Turun yliopistoon kieliopintoihin ja sieltä edelleen kieli-instituuttiin, jossa kääntäjän koulutus kesti kaksi vuotta. Instituutissa hän sittemmin työskenteli myös tuntiopettajana ennen siirtymistään pääkaupunkiseudulle ja ryhtymistään freelancer-suomentajaksi.

Suominen on kääntänyt lähes sata teosta. Hänen pääkielensä on ollut alusta alkaen saksa, joka tuli enemmittä pohdinnoitta tyttölyseossa ensimmäiseksi vieraaksi kieleksi. Lamavuosina Suominen alkoi kääntää myös ruotsista.

- Silloin oli onnellinen, jos sai joitakin töitä, suomentaja lausahtaa mietteliäänä.

Kun Suomiselta kysyy, olisiko hänestä voinut tulla kirjailija, tulkki tai opettaja, hän 
vastaa kielteisesti kahteen ensimmäiseen:

- Itsellä ei ole tarvetta sanoa eikä sanomaa. Kirjallisuudessakin minua kiinnostaa ennen muuta ilmaisutapa, tietysti tarina, rakenne ja muukin, mutta jos kieli mättää, niin ei tekstiä jaksa lukea. Eikä minusta olisi tullut tulkkia, kun en ole nopeasti reagoiva ja inhoan esiintymistä. Opettaja minusta kuitenkin tavallaan tuli, Suominen huomauttaa viitaten kieli-instituutin aikaan ja pitämiinsä Kääntäjäliiton kursseihin.

Yksi kääntäjän työn hyvistä puolista on Suomisen mukaan se, ettei tarvitse olla jatkuvasti julkisuudessa.

- Ei tarvitse antaa haastatteluja, ei esiintyä joka paikassa eikä kiertää puhumassa työstään. Saa tehdä työtään rauhassa välittämättä myynnistä, hän selittää ja kauhistelee mediapyöritykseen joutuvien kirjailijoiden asemaa.

Muitakin hyviä puolia Suominen löytää ammatistaan:

- Se on sivistävää työtä, siinä oppii jatkuvasti uutta, ja koskaan ei ole valmis. Lisäksi olen saanut kääntää hyviä kirjoja ja kääntäjänä pääsen niihin syvemmälle kuin kirjaan yleensä. Ja on siinä sekin ilo, että voi tuoda toisille sellaisia kirjoja, joista itse pitää.

Kääntäjän työn huonoista puolista Suominen mainitsee yksinäisyyden. Ja joskus myös säikähtää, että onkin kääntänyt kaiken aivan väärin.

Suominen puntaroi uraansa ja sanoo kokeneensa antoisimmaksi sen, että on saanut tehdä töitä hyvän kirjallisuuden parissa. Joskus aamuisin hän jopa huomaa havahtuvansa kääntämisen ihanuuteen, löytävänsä todellisen työnilon:

- Kun aamulla herään, niin ajattelen, että ihanaa, kun taas pääsen kääntämään! Tunne on kuin flow, kuin olisi virrassa, niin että kaikki tuntuu helpolta ja kaikki sujuu. Useimpien kirjojen kohdalla tulee hetki, että kaikki muu tuntuu sivuseikalta, huushollikin hoidetaan vasemmalla kädellä, ja vielä illalla myöhään tekee mieli mennä kääntämään.

Toisaalta Suominen tunnustaa myös aloittamisen vaikeuden:

- Kyllä työ usein takkuaakin eli joskus faktinen aloittaminen on aivan mahdotonta; tuntuu, ettei tästä selviä ikinä.

\section{Saksalainen kirjallisuus, ja suomalainen}

Millaisina Suominen sitten näkee saksalaisen kirjallisuuden kehityslinjat uransa aikana?

- En tiedä, voiko sieltä helposti löytää suuria linjoja, mutta modernissa kirjallisuudessa saksalaiset ovat ainakin tutkineet omaa historiaansa ennen suomalaisia. Vaikka kyllähän meilläkin on ruvettu enemmän, sanotaan nyt Väinö Linnan jälkeen, keskittymään näihin kipeisiin kohtiin.

Saksalaisesta kirjallisuudesta Suominen tunnistaa mieluummin monia suuria linjója, yhtä lailla vakavaa ja viihdettä, jokaiseen makuun jotakin. Suomessa modernista

ta mietteliäänä.

tai opettaja, hän 
saksalaisesta kirjallisuudesta on nostettu esiin erityisesti menneisyyden selvittämiseen ja tiedostamiseen keskittyvä kirjallisuuden suuntaus, Vergangenheitsbewältigung:

- Välillä tuntuu, että ainakin se kuva, mikä Suomessa on saksalaisesta kirjallisuudesta, keskittyy pelkästään tähän vaiettuun menneisyyteen.

Saksalaisessa kirjallisuudessa on kuitenkin lukuisia juonteita. Menneisyyden käsittelyyn keskittyvän suuntauksen Suominen näkeekin lähinnä ajallisen etäisyyden tarjoamana mahdollisuutena puhua myös kansallisesta menneisyydestä:

- Esimerkiksi 1990-luvulla Saksassa tapahtui Grassin ja Sebaldin toimesta se muutos, että alettiin vihdoin puhua saksalaisten kärsimyksistä sodassa.

Meillä saksalaista kirjallisuutta käännetään Suomisen mielestä niukasti. Hän laskee, että vuosittain julkaistaan suomennoksena noin kolmesta kahdeksaan teosta, jonakin vuonna ei yhtään. Suomalaislukijan käsitys saksalaisesta kirjallisuudesta muodostuu moniportaisen kaupallisen koneiston lopputuotteena:

- Suomennettavat kirjat tulevat Amerikan kautta, eli jos anglosaksinen maailma kiinnostuu jostakin kirjailijasta, silloin suomalainenkin kustannusmaailma innostuu siitä.

Esimerkkeinä Suominen mainitsee muun muassa Hermann Hessen, W. G. Sebaldin ja Bernhard Schlinkin.

Puhuttaessa saksalaisesta kirjallisuudesta ja sen annista suomalaisille Suominen muistuttaa, että saksa on Euroopan suurin kielialue. Sitä tulisi tuntea myös Suomessa.

- Ja onhan meillä yhteistä historiaakin, sekä hyvässä että pahassa, kääntäjä huomauttaa ja hakee perustavia yhtymäkohtia Lutherin uskonpuhdistuksesta ja protestanttisesta maailmankuvasta.

Toisaalta Suominen myös korostaa, että käännösten kautta on mahdollista välittää kulttuurista vierautta ja siten lisätä eri kulttuureissa elävien keskinäistä ymmärrystä.

\section{Kääntäjän asema}

Kääntäjänä Suomisella on ollut pitkä suhde esimerkiksi Kustannusosakeyhtiö Tammeen. Se ei kuitenkaan juuri ole antanut hänelle vapauksia valita suomennettavia teoksia. Sellaisia, joihin Suominen on itse voinut vaikuttaa, ovat muun muassa Nicolas Bornin Väärennös (Die Fälschung) ja Grimmin satujen käännöstyö. Niin ikään hän muistaa itsekin panneensa merkille Schlinkin, jonka kustantaja kuitenkin samaan aikaan oli huomannut.

Tietysti on myös teoksia, jotka Suominen olisi jo kauan halunnut kääntää, mutta joihin kustantaja ei syystä tai toisesta ole tarttunut. Niistä ensimmäiseksi hän mainitsee Grassin Peltirummun (Die Blechtrommel), josta nyt viimeinkin, sekä Suomessa että monissa muissa maissa, on tekeillä uusi käännös. Suominen on saanut suomennostyölleen reilusti aikaa: Peltirummun on tarkoitus ilmestyä vuonna 2009. Aarno Peromie- 
elvittämiseen ja tigung:

kirjallisuudesneisyyden käsittäisyyden tarjoimesta se muuisti. Hän laskee, teosta, jonakin sta muodostuu ksinen maailma ailma innostuu

n, W. G. Sebalisille Suominen nyös Suomessa. , kääntäjä huosta ja protestantadollista välittää ymmärrystä.

ssakeyhtiö Tamennettavia teokissa Nicolas Borään hän muistaa maan aikaan oli

t kääntää, mutta eksi hän mainitxä Suomessa että suomennostyölAarno Peromie- hen aiempaa suomennosta (1961) Suominen pitää jossain määrin vanhentuneena. Hänen mukaansa Peromies käänsi aikanaan vähän oudolle suomen kielelle, mikä tosin oli senaikainen tapa. Toiseksi yhä toteutumattomaksi käännöstoiveekseen hän mainitsee Thomas Mannin Buddenbrookit (Buddenbrooks), jonka aiempi suomennos on 1920-luvulta. Vaikka Mannia on jo käännetty muille kielille uudestaan, suomalaiskustantajat eivät toistaiseksi ole innostuneet.

Kun Suomiselta kysyy hänen suhdettaan eri käännöstöihin, saa kiinnostavan vastauksen:

- Sebaldin Austerlitz on ollut sekä vaikein että antoisin. Se on tyhjentymätön kirja. Ja tietysti sellainen, että siitä joko tykkää tai sitten sitä ei voi sietää.

Antoisaksi käännöstyöksi Suominen nimeää myös Benedict Zilliacuksen teoksen Kertomus kadonneesta saaresta (Båten i vassen), ja vähän mietittyään hän saa mieleensä monta muutakin rakasta käännöstyötä. Tärkeimmäksi kirjailijakseen hän nostaa Grassin, muttei osaa asettaa monia grassejaan järjestykseen. Erityisen hauskana tapauksena hän sentään mainitsee Kirjailijakokouksen (Das Treffen in Telgte).

Grassista Suominen puhuu mielellään ja ilmeisellä kunnioituksella. Hän on myös eri yhteyksissä kirjoittanut Grassin kääntämiseen liittyvästä problematiikasta (esim. teoksissa Ä̈̈ntä ja vimmaa, toim. Hannu Harju, 2004 ja Suom. huom., toim. Kristiina Rikman, 2005). Suominen on niin ikään kuvaillut kirjoituksissaan Grassin kääntäjille järjestettyjä seminaareja, joissa kirjailija itse opastaa ja vastaa teoksiaan koskeviin kysymyksiin. Seminaarit hän on kokenut antoisiksi: ne vähentävät tarvittavan taustatyön määrää, vahvistavat kääntäjien välisiä kontakteja ja lievittävät työn yksinäisyyttä.

- Siellä saa paljon taustatietoa, koska Grass puhuu Saksan historiasta. Eikä tarvitse lukea tietosanakirjoja kotona. Jää aikaa syventyä kääntämiseen.

Kiinnostavana Suominen näkee myös sen, kuinka erilaisia asioita esimerkiksi japanilainen ja ruotsalainen kääntäjä voivat pohtia ja millaisiin kysymyksiin etsiä vastauksia. Grassin kulloisenkin kirjan ilmestyttyä kukin käännösoikeudet saanut kustantaja on velvollinen lähettämään kääntäjänsä seminaariin. Urakasta voi toki koettaa selviytyä ilman seminaariakin, mutta Suominen kertoo osallistumisen aina helpottaneen työtä. Tuorein seminaarikokemus hänellä on kesäkuulta 2005 Gdanskista, missä aiheena oli Peltirummun kääntäminen.

Grass on ainoa säännöllisesti kääntäjäseminaareja järjestävä kirjailija. Muutamat muut ovat pitäneet seminaareja satunnaisesti. Suominen on kuitenkin ollut yhteydessä moniin kääntämiinsä kirjailijoihin, useimmiten sähköpostitse tai kirjeitse. Muutamia hän on tavannutkin.

- Jotkut vastaavat kiltisti, toiset vähemmän kiltisti. En muista, että kukaan olisi jättänyt vastaamatta.

Kaikki kirjailijat eivät toki ole yhtä kiinnostuneita, varsinkaan kun kyseessä on jo- 
kin suomen kaltainen pieni kielialue. Kysyminen ei usein olisi välttämätöntä, mutta Suominen tekee sen uteliaisuudesta; se on osa kääntäjän luonteenlaatua. Hän ottaa avukseen usein käyttämänsä vertauskuvan kääntäjästä muusikkona, korkeintaan joskus sovittajana, muttei koskaan itse säveltäjänä:

- Kyllä käännös on minun tulkintani eli minä soitan nuotit, kuten haluan. Silti haluaisin kuulla, miksi kirjailija on kirjoittanut nuotit juuri noin.

\section{Käännösprosessi}

Suominen on saanut työstään runsaasti tunnustusta. Vuosien varrella on kertynyt palkintoja, apurahoja ja palkkioita, jotka lämmittävät mieltä. Vaatimattomuuttaan hän toteaa, että kokee joskus saaneensa niitä liikaakin. Vuonna 2005 Suomiselle myönnettiin myös taiteilijaeläke. Työnsä hän on kokenut todelliseksi pätkätyöksi, josta tosin on nauttinut:

- Se on aina sopinut sekä psyykelle että elämäntilanteelle. Valitan yleisellä tasolla, mutta silti sanon, että päivääkään en vaihtaisi pois. Ja minulla on kyllä kaikkea, mitä tarvitsen, hän lisää ja silmäilee ympärilleen viihtyisässä Espoon kerrostaloasunnossaan.

Pelkillä käännöspalkkioilla ei Suomisen mukaan elä tai toimeentulo ei ainakaan ole mitenkään itsestään selvä. Perheen elättäminen on usein kovaa. Lisäksi Suominen näkee talouden hallinnan vaikeaksi monille kääntäjäpersoonallisuuksille:

- Kun meissä kuitenkin on myös jonkin verran taiteilijaa, niin näyttää olevan vaikeaa, kun saa äkkiä tililleen monta tuhatta euroa rahaa ja sitten täytyy muistaa, että sen onkin riitettävä puoleksi vuodeksi.

Suominen ei ole suostunut tekemään työtä alipalkalla. Päinvastoin hän kertoo saaneensa koko uransa ajan keskivertoa parempia palkkioita. Nykyisin kääntäjiä vaivaavat aikapula ja sen tuomat ongelmat. Suominen ei valita, mutta toteaa erityisesti amerikkalaisiin bestsellereitä suomentaviin kollegoihinsa viitaten, ettei suunta ole ollut hyvä. Myöhästyminen sovituista aikatauluista merkitsee kääntäjälle joutumista huonoihin kirjoihin. Aikataulut eivät välttämättä ole kiristyneet, mutta nykyään niistä on pidettävä ehdottomasti kiinni, ja joskus niitä jopa aikaistetaan kesken kaiken. Aiemmasta joustavuudesta luopuminen ja nykyinen aikataulujen ehdottomuus huolestuttavat Suomista:

- Olisi hyvä, että alitajunnalle jäisi aikaa toimia, ettei olisi aina niin kiire, kääntäjä huokaisee.

Suominen tietää joidenkin kääntäjien joutuvan joskus tekemään työtä lähes tauotta tai siten, että työrupeamien väliin jää vain muutamia nukuttuja tunteja. Hän selventää esimerkkiään oman kokemuksensa kautta: Jo pelkästään yön yli nukkuminen voi ratkaista monta ilmaisun ongelmaa, koska alitajunta on työstänyt niitä nukkumisen aikana. Suominen muistaa myös aamuisen hämmästyksensä, kun sormet näppäimis- 
ätöntä, mutta ua. Hän ottaa reintaan joskus n haluan. Silti n kertynyt palmuuttaan hän iselle myönneti, josta tosin on yleisellä tasolla, ä kaikkea, mitä loasunnossaan. ei ainakaan ole i Suominen nä-

ttää olevan vainuistaa, että sen hän kertoo saaäntäjiä vaivaavat ityisesti amerikca ole ollut hyvä. nista huonoihin niistä on pidetiken. Aiemmasis huolestuttavat in kiire, kääntäjä yötä lähes tauotta teja. Hän selvennukkuminen voi iiitä nukkumisen ormet näppäimis- töllä äkkiä löytävät oikean ilmaisun viimeistelyvaiheessa, jo ennen kuin johonkin ongelmaan on ehtinyt mielessään löytää mitään korjaavaa ratkaisua:

- Sormenpäät ajattelevat joskus paremmin kuin aivot.

Varsinaisen käännösmetodinsa hän toteaa pysyneen likimain samanlaisena läpi vuosikymmenten. Lähinnä tekniikan kehittyminen, kuten tekstinkäsittelyohjelmat, on vaikuttanut käytäntöihin. Edelleen kuitenkin tehdään raakavedos, siihen korjataan kynällä ja lopulta tullaan "puhtaaksi kirjoittamiseen" eli viimeistelyvaiheeseen. Vertailuun Suominen käyttää toisinaan ruotsinkielisiä käännöksiä.

Käytännön työprosessi eroaa kuitenkin jonkin verran erilaisten tekstien kääntämisen osalta. Suominen on määrällisesti tehnyt käännöksiä paljon - suomentanut muun muassa monia kymmeniä romaaneja - mutta myös lajien kirjo on lavea: romaaneja, novelleja, runoja, satuja, dekkareita, muistelmia, tietokirjallisuutta...

- Siitä puuttuvat vielä kuunnelmat, Suominen lisää. - En ole yhtään näytelmää kääntänyt, mutta kuunnelmat ovat vähän sinne päin.

Käännöstöitten eroja hän valaisee vertaamalla Sebaldin Austerlitz-romaanin ja Ingrid Nollin dekkareiden suomentamista. Austerlitz vaati Suomiselta monia lukukertoja. Salapolisiiromaanin kohdalla tilanne on toinen:

- En minä dekkaria lue hirveän monta kertaa etukäteen, koska se ei kestä sitä. Se pitää kääntää nopeasti, niin että tekstiin tulee mukaan sen vauhti.

Kun erilaisille kohdeyleisöille suomennetuista kirjoista tulee puhe, nousevat esiin Grimmin sadut. Niitä Suominen on kääntänyt yhdessä Raija Jänicken kanssa. Hän kertoo heillä aluksi olleen Anni Swanin ja Helmi Krohnin tekstivalikoimat, mutta niiden pohjalta ei työstä tullut mitään. Kaikki aloitettiin alusta. Sadut jaettiin tasan, ja Suominen ja Jänicke toimivat toistensa kustannustoimittajina eli lukivat toistensa käännöksiä äärimmäisen kriittisesti. Grimmin satujen kääntämistä Suominen pitää jonkinlaisena elämäntyönään. Yhdelle suomentajalle se olisi hänestä ollut liian rankka projekti moninaisuudessaan, esimerkiksi vanhojen ja murteellisten tekstien vuoksi.

Suominen opiskeli käännösteorioita pari vuotta ja tutustui niistä muutamiin. Mitään teoreettista kokonaisnäkemystä hänellä kuitenkaan ei omien sanojensa mukaan ole.

- Mutta ei niistä haittaakaan ole, hän huomauttaa ja kertoo usein käännösteorioita lukiessaan kokevansa, että ajattelee pitkälti samoin.

Hän muistelee, kuinka 1950-luvulla ja vielä 60-luvullakin käännökset pyrkivät selittämään eikä se 1960-70-luvullakaan ollut yhtä ammattitaitoista kuin nykyään. Samalla Suominen tunnustaa, ettei itse jälkeenpäin halua lukea omia käännöksiään, koska vain harvoin tarjoutuu tilaisuus korjauksiin:

- Kyllähän se vähän kiusallista on. Aina sieltä huomaa jonkun kohdan, jonka olisi voinut sanoa toisinkin. Joka kerta, kun soittaa ne nuotit, tekee erilaisen tulkinnan. Se 
on konsertissa ihan hyväksyttävää, mutta kääntäjä ei juuri koskaan pääse käännöstään korjaamaan.

\section{Kääntäjä ja kielen erot}

Keskustelu vie kääntämisen hienosäätöön. Puhutaan suomen ja saksan kielellisistä eroista, joista Suominen on kirjoittanut useissa yhteyksissä. Suominen kertoo, että vieraskielisestä ilmaisusta on ensin päästävä irti ja vasta sitten mietittävä, miten suomalainen sanoisi tällaisia asioita. Eteen tulee murteellisuuksia ja äidinkielelle vieraita ilmiöitä. Miten esimerkiksi kirjailijan tahallaan käyttämä artikkelittomuus oikein suomeksi käännetään? Entä miten puolalainen käännöksessä saadaan puhumaan suomea? Tai kuinka selvitä kieliopillisista erilaisuuksista, kun kieltosana kieltää saksassa eri asiaa kuin suomen kieltoverbi? Kun Suominen mainitsee yhden päänvaivaa tuottavan tapauksen, tullaan jälleen vääjäämättä Grassin teosten kieleen:

- Pitää esimerkiksi löytää suomen kielestä vastine Grassille tyypilliselle tavalle yhdistää samaan verbiin kaksi hiukan eri tavalla miellettyä objektia.

Samoin esiin nousee saksan kielen erikoisuus, pitkä lause, jota Suominen pitää ehkä sen vaikeimpana piirteenä:

- Pitkä lause ja sen rakentaminen sellaiseksi, että se toisaalta noudattaa saksalaisen kirjailijan ajatuksen kuljettamista ja toisaalta näyttää suomelta. Aina ei saa molempia oikein: sekä yhden lauseen sisäistä rakennetta että koko tekstin koheesiota.

Kielen erilaisuuden ongelmat näkyvät myös laajemmin.

- Saksassa abstraktisubstantiiveja on niin helppo muodostaa, eikä suomi siinä kerta kaikkiaan tule perässä. Saksan ja ranskan abstraktisuus on meille vaikeaa, koska suomi on hyvin luonnonläheinen, konkreettinenkin kieli.

Entä sitten mies- tai naiskirjailijan kieli ja ilmaisu? Eroavatko ne toisistaan?

- Olen niin paljon kääntänyt mies- ja niin vähän naiskirjailijoita, Suominen laskeskelee.

Ingrid Nollin dekkareihin sekä Christa Wolfin romaaneihin hän kuitenkin viittaa:

- Nollia on ollut helppo kääntää ja meillä synkkasi heti. Wolf taas on hyvin miehinen kirjailija tietyllä tavalla. Hänellä on niin jylhiä aiheita, vaikka hän kirjoittaa naisista ja naisille.

Esimerkiksi Suominen poimii Wolfin Medeian, jossa kertoo kohdanneensa selvän eron ja ongelmallisuuden siinä, miten Wolf naiskirjailijana kirjoittaa sekä naisen että miehen suulla.

\section{Kieli, käännös ja traditio}

Suomentajan täytyy tuntea ennen muuta kulttuuri, jossa käännettävät teokset ovat syntyneet. Konkreettinen kielen ja kulttuurin keskellä käyminen on tarpeen jokaiselle 
e käännöstään

an kielellisistä en kertoo, että vä, miten suokielelle vieraita uus oikein suoimaan suomea? aksassa eri asiaa tuottavan tapaiselle tavalle yhainen pitää ehkä attaa saksalaisen ei saa molempia iota.

suomi siinä kerta eaa, koska suomi oisistaan?

a, Suominen laskuitenkin viittaa: s on hyvin miehikirjoittaa naisista danneensa selvän la sekä naisen että tävät teokset ovat tarpeen jokaiselle kääntäjälle.

- On ehdottoman välttämätöntä, että olisi edes kerran käynyt maassa. Vaikka ei se aina tietenkään ole kohtuullinen vaatimus.

Yhtä tärkeänä Suominen omalla kohdallaan pitää kosketusta elävään kielenkäyttöön. Hän kertookin työskennelleensä vuosien mittaan useita kertoja Saksassa, Straelenin Übersetzerkollegiumin tiloissa, jonne hän suuntasi kolmeksi viikoksi myös marraskuussa 2005.

- Kaupungissa ei ole edes elokuvateatteria, Suominen kuvailee tarkoituksellisen virikkeettömiä työoloja. - Toki voi keskustella muiden kääntäjien kanssa, vaikka kukin keskittyykin omaan työhönsä.

Straelenissa Suominen kertoo laittavansa itse ruoan, käyvänsä kaupassa, pankissa ja tarvittaessa lääkärissäkin. Sen, että kieli ympäröi kaikkialla, hän näkee hyvin tärkeänä.

Kieli pitää kääntäjän tietenkin tuntea, mutta kuinka paljon pitää seurata saksalaista kirjallisuutta tai jopa Saksan yhteiskunnallista kehitystä? Suominen myöntää, että kääntäjän pitäisi tietää kaikki: tuntea koko kulttuuripiiri, pelata vaikka golfia ja kaikkia mahdollisia korttipelejä. Vaatimus on tietysti mahdoton.

- On tärkeää, että kääntäjä osaa sijoittaa saksalaisen kirjallisuuden oikeaan ympäristöönsä, Suominen korostaa ja mainitsee esimerkkinä Grassin Peltirummun sijoittumisen Gdanskiin.

Hän on tyytyväinen, että pääsi kääntäjäseminaarin yhteydessä kulkemaan kirjailijan lapsuuden katuja.

- Saksalaista kirjallisuutta pitäisi tietysti tuntea paljon enemmän, kuin mitä tunnen, mutta vielä tärkeämpi vaatimus on se, että lukee suomalaista kirjallisuutta, Suominen painottaa.

Kääntäjän on tunnettava oman maansa kirjallinen traditio, ja sen hallinta myös näkyy Suomisen käännöksissä. Esimerkiksi Grassin Avarammille aloille -romaanin (Ein weites Feld) taustalla on paljolti suomalaisille tuntematon Theodor Fontanen tuotanto, muun muassa Effi Briest-romaani. Sen suomennoksesta (J. A. Hollo) taas löytyvät sanat "avarille aloille", josta sitten nimimukailu Grass-suomennoksellekin. Hieman vastaavia esimerkkejä tulee mieleen muitakin. Suominen nyökyttelee esimerkiksi kysyttäessä Schlinkin novellikokoelman, Neuvottoman sukupolven, yksittäisen novellin nimeä ja sen yhteyttä Heinrich Heinen runoon ja edelleen Otto Mannisen Heine-suomennokseen: Siinä missä Schlink viittaa Heinen runossa esiintyvään ilmaisuun "Zuckererbsen", Suomisen käännös taas poimii "Sokeripapunsa" Mannisen Heine-suomennoksesta. Suominen myöntää, että valinnat ovat vaikeita, varsinkin kun on kyse arvostettujen aiempien kääntäjien töistä:

- Ei oikeastaan voi olettaa, että kukaan muistaisi esimerkiksi tuota Mannisen säettä mistään. Mutta jos tarkistaisi, niin... 
Käännöksissään Suominen on silti useimmiten välttänyt turhia selityksiä, koska on halunnut luottaa lukijan kykyyn selvitä ilman niitä:

- Kyllä teoksen pitää toimia ilman selityksiäkin. Ja onhan minulla selityksiä muutamissa teoksissa, kuten juuri Grassin Avarammille aloille -romaanissa.

Kääntämiensä teosten nimistä Suominen toteaa, että ne ovat suurelta osin kustantajan päättämiä:

- Kun kirjan nimi ei ole suoraan käännettävissä, kääntäjällä ei ole kovin paljon sananvaltaa. Siitä päättää kustantaja, koska se on markkinointia.

Esimerkiksi molempien suomentamiensa Schlinkin teosten nimistä Suominen muistaa esittäneensä eriävän mielipiteen. Lukijan (Der Vorleser) nimeksi hän ehdorti jotain sisällöstä nousevaa, mutta turhaan. Siitä tuli Lukija, koska The Reader oli jo tuttu englannista.

Suominen myöntää, ettei Schlinkin toisen teoksen alkuperäinen nimi Liebesfuchten taivu suomeen yhtä hyvin kuin ruotsiin tai englantiin.

- Ei se ole 'neuvoton' eikä 'sukupolvi', Suominen tokaisee.

Hän kertoo ehdottaneensa Neuvottoman sukupolven tilalle nimeä "Rakkaudesta pois", muttei saanut tahtoaan lävitse.

Toisenlaisiakin esimerkkejä on:

- Grassin kirjojen nimiä olen kyllä tehnyt, Suominen naurahtaa ja muistelee esimerkiksi Grassin Kopfgeburten-romaanin suomalaisen nimen syntyä, päässä syntymistä:

- Itse tykkäsin sananmukaisesta, jossa oli synnytys mukana, mutta se ei kelvannut. Sitten sanoin, että pannaan Aivoituksia. Sen kustantaja hyväksyi heti.

\section{Hyvän kääntäjän eväät}

Suomentajan työ on vaikuttanut Suomiseen lukijana:

- En enää voi olla ihan viaton lukija. Varsinkin käännösten kohdalla pohdin, mitä alkutekstissä on mahtanut olla. Jos käännös on hyvä, pohdinnat kuitenkin unohtuvat.

Kääntäjäkollegoistaan Suominen puhuu kunnioittavaan sävyyn. Erityisesti hän on arvostanut Kyllikki Härkäpäätä, jonka käännöksissä näkee yhdistyvän sekä tarkkuuden että toimivan suomen kielen.

- Härkäpää olisi tyytyväinen, että Carpelanin suomentaminen siirtyi hänen jälkeensä Suomisen tehtäväksi, hän arvelee kollegaansa ja ystäväänsä muistellen.

Nykykääntäjistä Suominen taas nostaa arvostaminaan esiin esimerkiksi Anna-Maija Viitasen ja Kersti Juvan.

Millainen sitten Suomisen mielestä on hyvä kääntäjä? Ja mikä aloittelevalle kääntäjälle kokeneelta ohjeeksi?

- Alkukielen taidon on tietenkin oltava niin hyvä kuin suinkin. Mutta ennen muuta kääntäjän pitää rakastaa äidinkieltään, Suominen korostaa. 
ksiä, koska on

lityksiä muuta-

ta osin kustan-

covin paljon sa-

istä Suominen

ksi hän ehdotti ader oli jo tuttu

imi Liebesfluch-

kaudesta pois",

uistelee esimerä syntymistä: se ei kelvannut.

lla pohdin, mitä akin unohtuvat. rityisesti hän on sekä tarkkuuden

iirtyi hänen jälistellen.

kiksi Anna-Mai-

rtelevalle kääntä-

utta ennen muu-

Filologisten taitojen ohella on kartutettava myös yleissivistystä. Antiikkia ja Raamatun perinnettäkin olisi hyvä tuntea. Kyky sijoittaa asiat oikeille paikoilleen karttuu vähitellen. Ennen kaikkea Suominen kuitenkin kehottaa kääntäjiksi aikovia lukemaan paljon:

- Pitää olla kirjallisuuden rakastaja ja pyrkiä siihen, että hyvän kirjan kaikki tasot jossakin määrin voitaisiin sanoa äidinkielelläkin.

On niin ikään luettava kaikenlaista sekä alkukielellä että omalla äidinkielellään, jotta kertyy monipuolinen sanavarasto ja tyylitaju kehittyy. Myös kääntämisen traditio on tunnettava, vasta sitten siihen voi ottaa kantaa. Mielikuvituksen osuutta kääntäjäksi aikovan ei kannata vähätellä, ja uteliaisuus ja suvaitsevaisuus ovat nekin osa sitä luovuutta, joka tuottaa elävää tekstiä. Ne myös Suomisen mukaan synnyttävät kokonaisnäkemyksen ja tulkinnan.

- Kääntäjä kuulee tekstistä sellaistakin, mitä eivät mitkään sanakirjat selitä. Kääntäjä pääsee tekstiin ikään kuin syvemmälle, Suominen hymyilee.

Tavallinen lukija voisi hyvällä syyllä tuntea kateutta kääntäjän, kirjailijan, kielen ja teoksen välisestä tiiviistä suhteesta, mutta jättää sentään tuntematta. Tunnustaa vain nöyrästi, että kääntäjä on lukijalle kullanarvoinen.

Haastattelu on tehty Espoon Viherlaaksossa 26.10.2005. Joulukuussa 2005 Bo Carpelanin romaani Berg (Kesän varjot) sai kaunokirjallisuuden Finlandia-palkinnon. Teoksen suomentajaa, Oili Suomista, kiitettiin valintaperusteluissa ansiokkaasta käännöksestä.

Oili Suominen s. 24.2.1941 Porissa. Asuu nykyään Espoossa.

\section{Palkintoja mm.}

Mikael Agricola -palkinto (1981), kääntäjien valtionpalkinto (1981), pitkäaikainen taiteilija-apuraha (1990-2003), J. A. Hollon palkinto (1993), Pro Finlandia -mitali (1999), kirjallisuuden valtionpalkinto (2003), taiteilijaeläke (2005).

\section{Suomennoksia mm.}

Günter Grass: Kampela (1979), Kirjailijakokous (1980), Aivoituksia (1982), Koiranvuosia (1985), Rottarouva (1987), Häpeän kieli, Intian päiväkirja (1989), Kellosammakon buuto (1992), Avarammille aloille (1996), Löytötavaraa lukuhaluttomille (1997), Minun vuosisatani (1999), Ravunkäyntiä (2002); Siegfried Lenz: Saksantunti (1973), Majakkalaiva (1977), Kotiseutumuseo (1980), Nicolas Born: Väärennös (1981); Christa Wolf: Kassandra (1985), Kesänäytös (1989), Medeia (2000); Hermann Broch: Unissakulkijat I-III(1988-1994); Erich Auerbach: Mimesis - todellisuudenkuvaus länsimaisessa kirjallisuudessa (1992); Grimmin sadut I-III (1999); Ingrid Noll: Kukko on kuollut (1997), Apteekkari (1999), Rakkaat vainajat (2004); Bernhard Schlink: Lukija (1998), Neuvoton sukupolvi (2001); W. G. Sebald: Austerlitz (2002), Vieraalla maalla (2004); Benedict Zilliacus: Kertomus kadonneesta saaresta (1990); Bo Carpelan: Kesän varjot (2005). 